\title{
Local Government's Integrity and Strategy in Tourism Development Based on Creative Economy in Kerinci Regency
}

\author{
Rahma Sri Wahyuni ${ }^{1}$, Syamsir ${ }^{2}$ \\ \{rahmasriwahyuni1503@gmail.com ${ }^{1}$, syamsirsaili@yahoo.com² ${ }^{2}$ \\ Master of Public Administration Course, Faculty of Social Sciences, State Universitas Negeri Padang, ${ }^{1}$ \\ Lecturer Faculty of Social Sciences, State University of Padang. ${ }^{2}$
}

\begin{abstract}
The purpose of this research was to formulate local government's integrity and strategy in tourism development based on creative economy in Kerinci Regency, Jambi Province. This research will provide solutions and strategies to improve the economy of the local community, considering that Kerinci regency tourism is designated as tourism branding for Jambi Province. With the formulation of policies, it is expected to be able to boost the income of the community around the middle to lower class economy, considering that the majority of people are farmers and gardeners. The research method used in this study was descriptive with qualitative analysis. Data collection was carried out by means of technical interviews with the government of Kerinci Regency such as the subdistrict head, village head, tourism agencies, business actors, local communities and tourist attractions. Data were also collected through observation and study documentation. The analysis technique used in this study was interactive analysis where the data collected was then reduced, presented, and concluded. It is hoped that this research can contribute for the development of tourism-based creative economy which is able to combine natural beauty, culture, culinary delights and local products in Kerinci Regency.
\end{abstract}

Keywords : Integrity, Tourism, Creative Economy, Economy.

\section{Introduction}

Indonesia has entered the era of the industrial revolution 4.0, which is a revolution that fundamentally changes the way of life, work and relate to one another. The industrial revolution is marked by the emergence of technological updates that will bring about many changes and risks that may arise, one of which is the increase in unemployment according to Ridwan Aji Pitoko, Aprillia Ika, ed, [1]. Human Resource Competence is the main key in entering the industrial revolution 4.0. Improving the quality of human resource competencies is very important, especially because Indonesian human resources are still not utilizing the latest technology. The sophistication of technology in the business world needs to be addressed carefully and on target. Therefore, it is important to prepare the competence of Human Resources so that they are of quality, integrity, creative and innovative.

Bureaucratic integrity is the first step towards realizing good government governance (good gonvernance). In other words, bureaucratic integrity is an effort to build a government that is 
more efficient in carrying out national development. Government bureaucracy can be likened to the engine of development and public services. Thus, to provide optimal public services to the community, a bureaucracy that is transparent, accountable, and free from corruption, collusion and nepotism $(\mathrm{KKN})$ is needed. In realizing good governance, building integrity is of paramount importance. This is because the character of integrity is very contrary to the character of corruption, as quoted from an article on the Anti Curruption Clearing House website which states that integrity has the opposite meaning of corruption [2]. Integrity is a good character of a human being or a good culture of an organization that creates a motivation for the owner to make decisions and actions for the common good. Meanwhile, corruption is an act of abuse of power by manipulating the common good for certain personal interests.

Tourism has an important role in increasing a country's foreign exchange as well as in increasing regional income. Kerinci Regency, Jambi Province as an area that has abundant natural wealth and diverse cultures, is a potential tourist attraction that is scattered throughout the Kerinci district. Potential tourist objects can be in the form of natural beauty, culture, historical places, cultural events and entertainment venues [3]. The tourism sector is able to open business opportunities and job opportunities to the surrounding community so as to improve the community's economy. Processing of tourist objects will also increase local revenue through tourist fees [8]. However, in reality the potential of the tourism industry has not been well optimized. Lack of tourist interest in visiting a tourist attraction can be caused by a lack of promotion, inadequate facilities and infrastructure and the products or services offered are not up to standard. So that local governments need to make strategic plans in tourism processing. One of the strategies in developing tourism is by developing the creative economy of the local community.

Rakib explained that easily accessible accessibility, the existence of good facilities and infrastructure as well as the products and services offered are important points in the development of the tourism industry This corresponds to pasal 14 Undang-Undang No 10 Tahun 2009 about tourism where it is explained that "The tourism business includes, among others (a) Tourist attraction; (b) tourism area; (c) tourism transportation services, (d) tour travel services; (e) Food and beverage services; (f) Providing accommodation services, (g) Organizing entertainment and recreation activities; (h) Organizing meetings, incentive trips, conferences and exhibitions; (i) Tourism information services; (j) Tourism consulting services; (k) Tour guide services; (l) Water tourism and; (m) Spa. " Therefore, Brahmanto, Hermawan and Hamzah explained that superior and quality tourism dance power is the main consideration in determining tourist destinations [4].

Jerusalem explains that the Creative Industry is an industry that has the authenticity of a person's talent, creativity and skills which can be used to generate income or to create jobs. Creativity is carried out by utilizing available resources using innovation and technology to produce competitive products. From the above definition, creative economy is explained as the result of the creativity and creativity of a person or group. The creative economy is expected to provide an increase in people's income and a source of regional income [4]. Weber explained that the uniqueness and characteristics of an area attracts tourists to come and visit again. Therefore the importance of developing the tourism industry by paying attention to highlight the characteristics and uniqueness of each region so that it becomes the superiority of the area [7]. 
The creative economy is expected to have a positive impact on improving the regional economy [4]. A tourism development strategy can be done by combining natural beauty with cultural arts performances, culinary tours and processing handicrafts that are unique to the area. Jambi Province consists of 9 districts and 2 cities. Where among the districts in Jambi Province, there is one regency that is the branding of Jambi Province tourism, namely Kerinci Regency which is the only district / city based on the Decree of the Governor of Jambi Number: 920 / KEP.GUB / DISBUDPAR.1 / IX / 2016 concerning The determination of the Kerinci National Tourism Strategic Area as a tourism branding for Jambi Province [5]. This determination is based on a study that Kerinci Regency has superior tourism potential in terms of quantity, quality and attractiveness compared to other districts / cities. The superiority of tourist destinations in Kerinci Regency is natural destinations, where the only area is in the highlands and precisely below Mount Kerinci, which is the highest mountain on the island of Sumatra. The 2017 Central Statistics Agency report noted that in Jambi Province there were 193 natural tourist objects, 98 of which were in Kerinci Regency [5].

However, the determination of Kerinci Regency as tourism branding for Jambi Province has not been accompanied by an increase in the quality of destination management as expected. This condition has resulted in no significant increase in the number of tourist visits, especially foreign tourists. In the end, the tourism sector has not been able to accelerate the development of the community's economic sector and has not contributed much to the increase in Regional Original Income (PAD) in Kerinci Regency. After four years of establishing Kerinci Regency as the tourism branding for Jambi Province, the data show that the number of tourist visits to Kerinci Regency has not increased significantly [5].

From the results of preliminary observations, according to the head of the Danau Kerinci sub-district, Mr. Pardinal explained that the tourist attraction that is always visited by local and international tourists is Lake Kerinci which is in the Danau Kerinci District, Lake Kaco which is in Gunung Raya District, Lake Langkas which is in Gunung Raya District. , do not have lodging and tourist mes that are no longer active in Kerinci Lake tourism. Mr. Pardinal added that tourism in Kerinci Regency still relies on nature and does not get the government's attention. The main income of the population does not come from tourism but from plantation and agriculture businesses, while tourism management is mostly managed by the private sector and does not contribute to the income of the surrounding population. The same thing was also conveyed by Mr. Edi Ruslan, Head of Kayu Aro Sub-District, that the minimal facilities and infrastructure have caused a lack of interest in tourists to visit again to enjoy the natural beauty of the Aroma Pecho area, Kayu Aro Tea Plantation and Kayu Aro Waterfall. Tourism development still relies on nature, lack of tourism promotion, lack of public awareness of the importance of the tourism industry as a source of income, ignorance of cleanliness and the environment, the products and services offered do not have consistent standards and the lack of support from the tourism office in tourism development are obstacles in industrial development tourism in Kerinci Regency.

Kerinci Regency is one of the tourist destinations in Jambi Province which has the potential for very beautiful natural tourism, both from the nature and culture of the area itself. Such as mountains, lakes, waterfalls, hot springs, caves, geoparks and various modern tours that are currently being developed. This certainly can contribute to increasing regional income through tourist visits to a number of tourist objects there as a driving force for the creative economy [6]. The government as the authorized official must pay more attention to tourism objects that have the potential to generate income and direct this sector as a driving 
force for a profitable creative economy in the future and provide good assumptions for tourists in the ease of procedures for binding attraction. However, it is not only income for government income but also welfare for the community around the tourist attraction. Handling tourist objects in increasing adequate human resources consistently, thoroughly, integrated and systematically by the Government to the community needs to be done because the success of strategic efforts to develop and manage tourism activities is an action, whether it is government, private or community action so that cooperation is created. which is kind and harmonious and embodies the Sapta charm [6].

The task of the bureaucracy in the regions is only as a facilitator (service). Community creativity is spurred and encouraged to develop. Tourism objects in Kerinci Regency can raise the regional economy and local communities if each object is well managed by the government and parties around these tourism objects so that the number of tourist visits will have an effect on increasing regional income [6]. The solutions referred to in this case are the integrity of the local government in a creative economy-based tourism development strategy to improve the economy of the people of Kerinci Regency, Jambi Province. Based on the description above, the formulation of the problems in this study are 1. What are the strengths, opportunities, threats and challenges faced by the community in increasing the tourism industry in Kerinci Regency. 2. How is the integrity of the government blood in the creative economy-based tourism development strategy to improve the economy of the people in Kerinci Regency, Jambi Province. Research Objectives The purpose of this research is carried out, namely: to provide ideas, input and ideas to the government of Kerinci Regency, business actors and the surrounding community about strategies to increase the tourism sector with a creative economy with the aim of providing a significant economic contribution, creating a conducive and positive business climate, creating a creative and innovative society, providing a positive social impact and reducing the level of poverty and the number of unemployed.

\section{Methodology}

This research is descriptive with a qualitative approach that aims to address the problems described in the research problem formulation. According to Sugiono [9], descriptive research aims to describe the reality of the events under study so that researchers are able to obtain objective data in order to develop a creative economy-based tourism development strategy to improve the economy of the local community. Population and Sample Sugiono [10] explained that the population is the whole of the subjects studied while the sample is part or representative of the population under study. In this study the samples studied were the tourism office of the Kerinci district, the sub-district head, village officials, tourism managers, business actors, local communities and tourists. Samples were obtained using a purposive technique which is selected by the researcher according to the capacity and consideration of the researcher. Data collection techniques This research uses primary data and secondary data. Primary data collection is done by making observations, interviews and documentation.

Observations on research objects in Kayu Aro District, Danau Kerinci District, Semurup Hot Water District, such as access to locations, facilities and tourist attractions (photo spots), cafes and resting places. Initial observations were made by direct visits to the sub-district and several villages to determine tourism potential, community activities and micro, small and medium enterprises, access to tourist attraction locations and available facilities to support the tourism 
industry. visited several villages to see firsthand the potential of the village and its tourism objects. Interview Primary data was obtained by conducting interviews with the sub-district head and village head to obtain data, the researcher conducted interviews with the sub-district head and several village heads to find out the potential and problems that exist in the development of the tourism industry in Kerinci Regency. To get complete primary data, interviews and discussions were carried out by sharing interview assignments with regional tourism offices, tourism managers, business actors, local communities to get actual pictures of the object of research as well as conducting interviews with visiting tourists to get an overview of the perceptions, needs and desires of tourists. Documentation Secondary data were obtained from reports from the Central Statistics Agency of Kerinci Regency, laws and regulations on tourism, documents from the District and Village Offices. Secondary data were also obtained from books, international journals and national journals related to management, integrity, tourism, human resources and the creative economy.

Data Processing Techniques Data collected from the field will be processed using data processing techniques, where the stages are carried out as follows: a. Editing; Editing techniques are carried out to review primary data obtained from the field both from interviews and documents from the Kerinci Regency tourism office. The goal is to avoid errors and mistakes in data usage. Selection of information that is appropriate and useful for research and that is not useful for research. b. Interpretation; Interpretation Techniques by interpreting the results of the interviews conducted. By understanding the meaning of each information obtained and relating it to the research topic. This activity is carried out by understanding, finding the essence of the information conveyed by each informant from the results of the interview. The data analysis technique used in this research is using Miled and Huberman's model in Sugiyono [10], namely Reduction, Data Display and Conclusion. Analysis is used to determine the factors that become a. Strengths such as natural potential, local products, traditional food, cultural performances, plantation agriculture and fisheries can be used as alternative tourist destinations. b. Weaknesses such as low tourism awareness, lack of local government support, minimal facilities and infrastructure, the tourism sector which is managed by the private sector does not involve local residents, no sustainable tourism planning, lack of cleanliness. c. Opportunities such as the establishment of Lake Kerinci as a priority for tourism development, massive infrastructure development in Kerinci Regency such as the construction of Depati Parbo Airport, road construction, and road repair in Kerinci Regency. d. Actions such as rejection of indigenous peoples, environmental destruction, deforestation and destruction of cultural sites due to visitors.

\section{Finding and Discussion}

\subsection{Tourism Objects in Kerinci Regency}

Tourism Objects in Kerinci Regency With the largest number of tourist attractions, this has the potential to support tourism activities in Kerinci Regency. Here are some tourist places / areas in Kerinci Regency. First, the Gunung Tujuh Lake area is located in Pelompek Village, Kayu Aro District, Kerinci Regency, Jambi Province, Indonesia. This lake was formed due to the eruption of Mount hundreds of years ago, located at an altitude of $1,950 \mathrm{~m}$ from the sea surface. With this height, Gunung Tujuh Lake is listed as the highest lake in Southeast Asia. The beauty of Lake Gunung Tujuh is more complete by the stretch of seven mountains that surround it and the Gunung Tujuh Waterfall and Telun Berasap Waterfall are other complementary parts. Second, Mount Kerinci, with an altitude of 3,805 m above sea level (asl), 
is the highest volcano in Indonesia. Another view of the slopes at the foot of Mount Kerinci is the Kayoe Aro Tea Plantation which was founded between 1925 and 1928 by a Dutch company, Namblodse Venotschaaf Handle Vereniging Amsterdam (NV HVA). This tea plantation is listed as the oldest tea plantation in Indonesia. Kayu Aro Tea Plantation covering an area of 3020 hectares is a tea plantation in one of the largest stretch in the world, located at an altitude of $1,400-1,600 \mathrm{~m}$ above sea level which is the second highest tea plantation in the world after Darjeling tea plantation at the foot of Mount Himalayas (4,000 m asl). Third, Lake Kerinci, which is located at the foot of Mount Raya, is the largest lake in Kerinci Regency, the area of this lake is approximately $46 \mathrm{~km} 2$ with an altitude of 783 meters above sea level. The scenery around the lake is so charming with a clear stretch of water against a backdrop of graceful mountain ranges around it. At Lake Kerinci, every year the Lake Kerinci Festival is held which displays various kinds of arts and cultural attractions of the Jambi people. The purpose of this festival is to provide treats to tourists who come to visit. Fourth, the Kerinci Seblat National Park (TNKS) is the result of the unification of several Kerinci nature reserves such as: Inderapura and Bukit Tapan Nature Reserve, Rawasa Huku Lakit-Bukit Kayu Embun Wildlife Reserve and Gedang Seblat. Given the vital role of the forest as the lungs of the world, on October 4, 1982, to coincide with the World National Park Congress held in Bali Province, the government made the Kerinci Seblat National Park area a protected forest area. In the Kerinci Seblat National Park area, in general, there are around 4,000 species of flora, while the fauna species recorded are 42 mammal species, 10 reptile species, 6 amphibian species, 306 bird species from 49 families and 8 endemic bird species. Apart from those mentioned above, there are many other natural tourist attractions in Kerinci Regency as well as other types of tourism as shown in Table 1.

Table 1. Leading Natural Tourism Objects in Kerinci Regency to Become Locus of Development Programs.

\begin{tabular}{lll}
\hline \multicolumn{1}{c}{ Attraction Name } & Type of Tourism & Location \\
\hline Danau Gunung Tujuh & Marine / Water & Pelompek, Kayu Aro \\
Danau Kaco & Marine / Water & Dusun Baru Lempur \\
Danau Kerinci & Marine / Water & Kec. Keliling Danau \\
Air Terjun Talang Kemulun & Marine / Water & Talang Kemulun \\
Air Panas Semurup & Health & Kec. Air Hangat \\
Masjid Agung Pondok Tinggi & Religion / Art & Pondok Tinggi \\
Pendakian Kerinci & Nature / Beauty & Bengkolan Dua \\
Danau Lingkat & Marine / Water & Lempur, Gunung Raya \\
Air Terjun Telun Berasap & Marine / Water & Gunung Tujuh \\
Air Terjun Pancuran Rayo & Marine / Water & Pulau Tengah \\
Kawasan Aroma Peko & Marine / Nature / Water & Bento, Kayu Aro \\
Goa Kasah & Nature / Art & Renah Kasah, Kayu Aro \\
Taman Nasional (TNKS) & Nature / Beauty & Koto Renah, Pesisir Bukit \\
Perkenunan Teh Kayu Aro & Natural & Giri Mulyo, Kayu Aro \\
\hline
\end{tabular}

Source: Disparbudpora Documents Kab. Kerinci 2020

The Integrity of the Government's Basics in the Implementation of Tourism Management in Kerinci Regency. Currently, overall tourism in Kerinci Regency is managed by two agencies, namely the Youth Sports, Culture and Tourism Service, and the Kerinci Seblat National Park (TNKS) and assisted by the community around the tourist attractions in Kerinci Regency. To find out the future strategy for developing Kerinci tourism, one must consider beforehand the implementation of management based on management functions to the main tourist attractions 
of Kerinci Regency, namely planning, organizing, mobilizing and monitoring which have been previously described.

\subsection{Strengths, Weaknesses, Opportunities and Threats of Tourism in Kerinci Regency}

a. Strength

By knowing its strengths, tourism can be developed to be more resilient so that it is able to survive in the market and be able to compete for further development. The strengths of tourism in Kerinci Regency, namely:

1. Nature tourism that can be used as a very good Outbound.

2. Many work and earn a living from tourists, such as to become guides for foreign tourists.

3. The availability of several homestays in natural attractions.

4. The government is very concerned about natural tourist attractions.

5. Private Sector Support In supporting leading tourist objects, the private sector is involved, one of which is the assistance of Bank Indonesia in providing seeds and equipment in village agricultural management to support the village as an Agro tourism object.

6. Tourism Awareness Group As a tourism village, the community has formed a tourism awareness group. this is a potential that can be managed properly. Sigapiton village has a tour group that runs the homestay.

7. Handicrafts and regional specialties as potentials that can be developed are the development and training for community businesses.

b. Weakness

Weakness is something that is not beneficial or detrimental to tourism. The weaknesses of tourism in Kerinci Regency, namely:

1. Lack of adequate human resources.

2. Inadequate infrastructure for natural attractions.

3. There are no star hotels for tourist lodging.

4. Remote access, road access to tourist objects is still very much of concern. There are several tourist attractions. The road can only be passed by 1 car and the road condition is still damaged.

5. Environmental Cleanliness The low level of public awareness of environmental cleanliness can be seen from the complaints of tourists who visit, from the observations it is also seen that there is still a lot of garbage scattered about and not cleaned by cleaners.

6. Toilet Cleanliness Public toilets are one of the important supporting facilities in tourism. From the observation that the public toilets are not well maintained. This is because there are no cleaners who carry out routine controls in toilet hygiene at any time

c. Opportunity

Opportunities are favorable environmental trends that can increase tourism in the Kerinci district, Kerinci regency tourism opportunities, namely:

1. The number of tourist attractions in the Kerinci Regency is very large and well-known in foreign countries.

2. Natural tourism in Kerinci Regency is very unique and interesting to visit.

3. Distinctive and unique souvenirs from the original handicrafts of the kerinci culture and special foods that are processed directly from the agricultural products of the kerinci region such as coffee, sweet skin syrup, potato lunkhead, and others. 
4. Small city center, so it doesn't cost much for transportation within the city.

5. Central Government Attention Central Government through the Festival of the People Caring for the Lake Kerinci (FMPDK) which is held annually.

6. Massive Infrastructure Development Massive infrastructure development carried out by the government is an opportunity in developing tourist attractions.

\section{d. Threat}

Threats are things that can bring harm to tourism, such as government regulations that do not provide ease of doing business, damage to the environment, transmission of AIDS, increased prostitution, or social unrest as a result of high costs and competition for more professional foreign tour operators. Several threats that can threaten tourism in Kerinci Regency, namely:

1. Frequent inactive air transport.

2. Land transportation which is far from the provincial capital.

3. The amount of damage to tourist attractions by humans themselves.

4. Damage and Extinction of Historical Sites Damage to cultural sites can occur due to the actions of tourists who are not aware of good behavior and behavior. Often tourists often take photos and selfies without paying attention to the environment, there are mischievous hands who want to destroy historical relics so that they can damage or eliminate historical remains.

\subsection{Local Government's Integrity in Tourism development at Kerinci Regency.}

The integrity referred to here is that according to Zahra, 2011 [2], integrity is a commitment to do everything in accordance with the correct and ethical principles, in accordance with the values and norms, and there is consistency to continue to carry out this commitment in every situation without seeing an opportunity or coercion to get out of principle, meaning that the person will try to work and carry out his duties properly in accordance with what he has planned before and is responsible for the task. So the integrity of the local government in tourism development in Kerinci Regency has been prepared in accordance with the management of the tourism destination development program, namely planning, organizing, mobilizing and monitoring. Furthermore, the results of research related to the management of the Kerinci Regency tourism destination development program until 2020 are presented, namely: first, planning is the act of selecting and connecting facts and making and using assumptions about the future in terms of visualizing and formulating activities that are proposed which are deemed necessary to achieve the desired results according to Siagan, 2012 [11]. In this case, there are four aspects of planning, namely, determining the vision and mission, formulating policies, determining the budget and determining organizational targets. Based on the results of the study, it was found that the Kerinci Regency Tourism, Culture, Youth and Sports Office had planned these four aspects according to the applicable regulations, which were then stated in the Strategic Plan document which was compiled every five years using the Kerinci Regency Regional Medium Term Development Plan 2019-2024. . The Strategic Plan is then described operationally in the annual work plan. As the results of interviews and documentation studies, in an effort to realize the vision of "Realizing Kerinci as a superior tourist destination that is competitive, sustainable and based on natural and cultural wealth towards a better Kerinci" is only supported by an average of three types of activities for the district tourism destination development program. Kerinci per year. These activities include: first, increasing the development of tourism facilities and infrastructure, second, improving tourism technical services in the three UPTDs, and thirdly, providing tourism facilities for tourism objects 
(ODTW). So in this case the local government must really take responsibility for the development of tourism in the Kerinci district according to the plan.

Second, Organizing is the act of seeking effective behavioral relationships between people, so that they can work together efficiently and thus gain personal satisfaction in carrying out certain tasks in certain environmental conditions in order to achieve certain goals or objectives. 2001 [12]. Based on the results of the research, it was found that the organization carried out in the field of Tourism Destination Development at the Kerinci Regency Tourism, Culture, Youth and Sports Agency used organizational lines and instructions. The regulation of duties and functions refers to the Regional Regulation of Kerinci Regency number 5 of 2016 concerning the Formation and Composition of the Regional Apparatus of the Kerinci Regency and each unit has understood the duties and functions of each. The Tourism Destination Development Sector is one of the five fields in the Kerinci Regency Tourism, Culture, Youth and Sports Office which is responsible for the tourism destination development program. The division consists of one head of echelon III a and three head of echelon IV a section and consists of four staff. The following is a table of the number of employees of the Kerinci Regency Tourism, Culture, Youth and Sports Office as a whole based on education level. Seen in table 2.

Table 2. Number of Employees of the Kerinci Regency Tourism, Culture, Youth and Sports Office Based on Education Level in 2018

\begin{tabular}{lccc}
\hline \multicolumn{1}{c}{ Level of education } & $\begin{array}{c}\text { Tourism } \\
\text { Education }\end{array}$ & $\begin{array}{c}\text { Education } \\
\text { Non Tourism }\end{array}$ & Total \\
\hline S.2 & 1 & 11 & 12 \\
S.1 & 0 & 27 & 27 \\
D.III & 2 & 0 & 2 \\
SMU / Sederajat & 0 & 6 & 6 \\
SMP / Sederajat & 0 & 2 & 2 \\
SD / Sederajat & 3 & 1 & 1 \\
& & 47 & 50 \\
\hline Total & 3 & & \\
\hline
\end{tabular}

Source: Disparbudpora Documents Kab. Kerinci 2020

Based on Table 2, it can be seen that the Kerinci Regency Tourism, Culture, Youth and Sports Office has employees, most of whom (78\%) have S1 and S2 educational qualifications. Meanwhile, $22 \%$ have high school education qualifications and below. However, out of 50 (fifty) employees, only 1 (one) person or $2 \%$ have a tourism education background, namely diploma three (D3) graduates. Thus it can be said that the field of tourism destination development itself has limited human resources, because only one person has a tourism education background. This causes the division of workloads received by employees sometimes not in accordance with their educational qualifications, so that the performance of the apparatus has not been realized as expected. So far, employee capacity building has been carried out through training, although the intensity of the implementation is still limited for the existing apparatus. Another obstacle, until now there has not been a cross-OPD tourism development coordination team, so it seems that tourism development in Kerinci Regency is only the responsibility of the Department of Tourism, Culture, Youth and Sports, because the roles of other OPDs have not been optimal. The existence of this team is considered very important as a forum for cross-sector coordination, but its formal stipulation has not yet been implemented.

Third, Actuating is an effort to create a climate of cooperation among program implementing staff so that organizational goals can be achieved effectively and efficiently 
according to Syamsi, 1998 [13]. After the division of duties and functions of each staff, then the staff carry out them in accordance with the leadership's instructions. The results showed that the management of the four leading tourist objects, especially in terms of service activities, was carried out by the technical service units at each location in accordance with the instructions of the head of the department. Meanwhile, other activities such as improving tourism facilities and infrastructure and developing tourism awareness groups or other similar groups are carried out by units in the Tourism, Culture, Youth and Sports Agency Tourism Destination Development Sector. All activities in the Tourism Destination Development program have been carried out well, this can be seen in the successful achievement of the performance indicator targets as outlined in the planning documents that have been prepared and the Government Agencies Performance Accountability Report (LAKIP). In the mobilization management function, there are obstacles, namely the unavailability of budget in the APBD, including the absence of budget support from the Jambi Provincial APBD and the APBN specifically for the development of tourism destinations in Kerinci Regency. Then another fact that occurs is the lack of involvement of the private sector and the community in developing tourist destinations. Meanwhile, in accordance with the current development of public management studies, collaboration in the management of the public sector, including the tourism sector, is needed. Collaboration according to Rozidateno, 2017 [12] is cooperation and relationships between organizations that are mutually agreed upon through a communication process. Meanwhile, Benton, 2013 [13] states that collaboration in the provision of public services that involves two or more levels of government (national, regional, regional and local) is not uncommon for collaboration to be carried out in various ways or strategically. The lack of cross-sectoral involvement can be seen in the inadequate availability of infrastructure and other tourism support facilities, so that some visitor needs have not been properly fulfilled. So the task of local governments in mobilizing this must really be carried out and become a burden and responsibility in the future.

Fourth, Controling can be interpreted as an effort to determine what is being carried out by assessing the results or achievements achieved and if there is a deviation from the predetermined standard then an improvement effort is immediately held so that all the results or achievements achieved are in accordance with Handayaningrat, 2007 ( 13]. The implementation of supervision and control by the Tourism Destination Development sector of the Kerinci Regency Tourism, Culture, Youth and Sports Office on the programs which are its duties and responsibilities has been carried out in accordance with the provisions. This is evidenced by the existence of routine internal evaluation meetings at least quarterly and other monitoring and evaluation activities by adhering to existing rules and regulations. The results of supervision and control are also summarized in the Government Agency Performance Accountability Report (AKIP) document and other related evaluation documents.

\subsection{Creative Economy-Based Tourism Development Strategy to Improve the Community Economy of Kerinci Regency, Jambi Province.}

Tourism development in Kerinci Regency to increase the number of tourists, it is necessary to have activities in tourism development :

1. Training for the community on Tourism.

Various training activities that need to be improved in tourism development in Kerinci Regency such as (a) Tourism service training, (b) Tourism awareness training both in communicating and serving tourists, (c) English language training, so that people are able to communicate and provide the best service to international tourists (d) Training in providing 
food according to tourist standards. (e) Training on the use of social media in order to promote village tourism and what products and services are offered.

2. Brand each tourist attraction as a strategy to increase the number of tourists visiting by branding and promotion on social media, websites and exhibition activities. This activity is one of the strategies to attract tourists from abroad where many foreign tourists have visited, starting from Singapore, Malaysia, Southeast Asian countries and the European Community.

3. Development of Facilities and Infrastructure Intensive repair of facilities and infrastructure must be accompanied by opening up opportunities for investors to invest and build tourist sites. With the presence of investors, it will increase improvements in tourism development. Development must also be followed by good maintenance. With the presence of cleaning officers, tourist officers who are always cleaners and improvements to the facilities that have been given.

4. Repair of sanitary facilities, sewage treatment, maintenance of toilets and parking is very important and a top priority. The development of facilities and infrastructure also needs to be done by providing a clear schedule for accommodation where the existence of good and standard public transportation can facilitate the access of local and foreign tourists to visit the village and to various tourist objects in the village or sub-district in Kerinci district.

5. Improving the quality of products and services as one of the supporting activities of tourism is by improving and enhancing the quality of the products and services offered. Where local products such as handicrafts, incung batik craftsmen, incung carvings, and art objects must be adjusted to tourism standards.

6. Agro Tourism Development One of the strategies to increase the number of tourists in Kerinci district is the need for the development of local products such as the culture of coffee, potatoes, ginger and other crops. For agro-tourism activities, it is carried out by involving tourists to see the process of making coffee, from roasting to serving. Arabica, Robusta, and other coffees which have different characteristics from other coffees in Indonesia.

7. Traditional food processing which has been standardized in Kerinci district has abundant natural resources, one of which is a potato producer with the management of potato dodol, potato chips and others which attract tourists, namely the food offered to tourists. With the existence of a serving process and regional specialties, it will be one of the unique things that attracts tourists to come to visit and stay in tourist objects.

8. Conducting scheduled festival activities One way to bring in tourists is by conducting various events in Kerinci Regency, one of which is the festival of the caring dananu kerinci community, national and international music events, well-packaged community annual events such as Harvest Events, and others

9. Clear Regulations In developing tourism in Kerinci Regency, tourism activities do not pose a threat to the tourism community. So that cultural values and local wisdom are not eroded in the midst of life today. The need for a good approach to the community so that things that hinder tourism development can be resolved properly

10. Collaboration with Other Agencies The need for community cooperation, local government with other agencies where several companies that can help develop tourism in Kerinci Regency are Bank Indonesia, Commercial Banks such as Bank Mandiri, Bank BCA, Bank BRI. PT Inalum, tour and travel companies, clan administrators in tourist areas, universities and educational institutions, school alumni who are in the tourist area.

11. Digital Technology Development One of the strategies in increasing the number of tourists and tourism promotion is to provide education to the public in the use of technology. The digital era is now very important so that all information can be conveyed to potential local 
and foreign tourists. It is also hoped that the development of digital technology will be very important because all foreign tourists are familiar with the use of technology.

12. Promotion, in addition to the means and infrastructure of policies that will be carried out are promotions that are very influential for the development of tourist objects in Kerinci district, the promotion factor also has a considerable influence on the achievement of tourism village development which is able to improve the economy of the community. Promotion is an effort to inform or offer products or services with the aim of attracting potential customers to buy or consume them. Good and correct promotion management will make these products and services attractive and able to make consumers feel they want them. One of the indicators of tourism development policies is promotion as the implementation of a harmonious and integrated marketing effort. Marketing is a very important activity, so that buyers get the maximum benefit with the least risk. Besides that, there is also accessibility, as a crosssectoral development, and the development of tourism areas and tourism products. Promotion is one of the determining factors for the success of a marketing program. Regardless of the quality of a product, if consumers have never heard of it and are not sure that it will be of use to them, then they will never buy it. In essence, promotion is a form of marketing communication. Meanwhile, marketing communication itself is a marketing activity that seeks to spread information, influence / persuade, and remind the target market of the company and its products to be willing to accept, buy and be loyal to the products offered by the company concerned.

13. The formation of a permanent management for tourist objects is an asset and a program that is prioritized for development by the regional government but the management of tourism in a tourist attraction is very weak, it can be seen from the equipment and facilities that are not yet visible. Even though the management is weak, basically tourism in Kerinci Regency means a lot for the community to improve the economy and provide a meaningful impetus for the development of tourism objects in the future. The principle of developing a tourist village is one of the alternative tourism products that can provide encouragement for sustainable rural development and has management principles, among others, are: (1) utilizing local community facilities and infrastructure, (2) benefiting local communities, (3) on a large scale small to facilitate the establishment of reciprocal relationships with the local community, (4) involving the local community, and (5) implementing the development of rural tourism products. the village and requires a strategy so that the planned strategy can benefit the surrounding community both economically, socially and culturally and become the initial capital in increasing Village Original Income (PADes) from the tourism sector.

14. Coordination with the Tourism Support Sector. As for the programs that will be carried out by local governments in the tourism sector, one of which is coordination with the tourism sector. The development of tourist objects carries a traditional concept by involving local communities to participate directly as management managers. At the pioneering stage of each tourist attraction, the role of the Integrity of the Regional Government for each tourist attraction is very decisive in achieving success. The development of capacity and capability (capacity building) initiated by the Regional Government is to increase performance optimally to support the achievement of economic development targets, reform human resources, increase individual capacity in the context of realizing community-based tourism object development

15. Tour Guide Training is one of the main activities in the Tourism marketing development program. Human resources are one of the basic assets in tourism development efforts. Human resources in the tourism sector must have the expertise and skills to provide tourism services and handle various tourism problems and various existing problems. The success of a 
development and development of the tourism sector in the village of Tanjung Alam also depends on the ability of the executors who are assigned to tourist destinations as well as the implementing apparatus for developing the tourism sector. One of the main strategies formulated by the kerinci district government is Human Resource Development where the important points in the development of human resources in question include: developing professionalism of human resources by providing training and education. Community empowerment in the context of tourism development is an effort to strengthen and increase the capacity, role and initiative of the community as one of the important stakeholders outside the government and private sector, to be able to participate and be active in strategies as subjects and as beneficiaries in sustainable tourism development. Considering the foregoing, the regional government has made a policy even though it has not been promulgated but it has been recorded as a Medium-Term Development Plan (RPJM) for each tourism object village. The development of tourism objects is gradual and comprehensive with a focus on the development of one tourism object and then stepping into the development of the tourism object itself, namely in the form of tourist equipment such as toilets, tourist attractions, lodging places, and other tourist infrastructure.

\section{Conclusion}

Based on the description above, it can be concluded that the integrity of the regional government in the creative economy-based tourism development strategy to improve the economy of the people of Kerinci Regency, Jambi Province has not been implemented properly and is still facing several obstacles from the aspects of planning, organizing, and mobilizing. Therefore it is necessary to make improvements in several aspects of the integrity of the regional government to increase the attractiveness and level of tourist visits both domestic and foreign to Kerinci Regency which has been designated as tourism branding for Jambi Province. From the research results it can be concluded that tourism in Kerinci district has different characteristics both in terms of Strengths, Weaknesses, Threats and Challenges which in terms of strengths get (a) full support from the central government both in terms of facilities and infrastructure; (b) there is support from other institutions both from private companies and educational institutions; (c) Homestay construction and repair; (d) Developing handicrafts (e) developing the Kerinci Lake Care Community Festival, in terms of weaknesses where (a) Access to damaged villages; (b) Environmental cleanliness that is still dirty; (c) Toilets that are still dirty and not well maintained; (d) Village development must obtain the approval of the village elder; (e) Tourist visits that are temporary in nature. In terms of tourism opportunities, (a) the attention of the central government; (b) Massive infrastructure development; In terms of tourism threats, where (a) Environmental damage due to massive development, including the construction of hotels, roads and others. (b) Damage and extinction of historical sites as a result of tourists.

Suggestions In the development of tourism in Kerinci Regency, several things need to be improved. 1. Local government has paid attention to the management of tourism potential by involving the community so that people can get great benefits for tourism development. So that community involvement can increase community income and society easily accepts tourism developments. 2 . The training provided must be in accordance with the needs of the community. Training is not just a formality but there is continuation and continuous mentoring so as to get maximum results 3 . There is good communication from the village apparatus, the central government with the local community. This is very important given the existence of several 
obstacles and problems, especially land disputes, which are one of the obstacles to tourism. 4 . Changes in people's thinking are carried out by using cultural, religious and socio-cultural approaches. This is so that all government programs can be implemented properly.

\section{References}

[1] Rohida, Leni. The Influence of the Industrial Reform Era 4.0 on Human Resource Competence. Journal of Indonesian Business Management. 2018; Vol 6 No 1.

[2] Widiastuti, C Tri; Widyaswati, Rhmatya; Meiriyanti, Rita. Strategies for Increasing Creative and Innovative Human Resources in Semarang Batik UKM (Study in Semarang Batik Village). Research and Technology Journal.2019; Vol 13 No 2; $124-130$.

[3] Widjaja, Yani Restiana; Almansyah, Doni Purnama; Rohaeni, Heni; Sukajie, Bambang. The Role of MSME HR Competencies in Improving MSME Performance in Cilayung Village, Jatinagor District, Sumedang. Journal ABDIMAS BSI. 2018; Vol. 1 No. 3; Hal. 465-476.

[4] Sedermayanti; Nurliawati, Nita. Strategies for Strengthening Ethics and Bureaucratic Integrity in the Context of Preventing Corruption to Improve Service Quality. Journal of Administrative Sciences. 2012. Vol. IX No. 3.

[5] Simarmata, Hengki Mangiring Parulian; Panjaitan, Nora Januarti. Tourism Development Strategy Based on Creative Economy in Improving the Community Economy of Toba Samosir Regency. Jurnal EK\&BI. 2019. Volume 2, Nomor 2; E-ISSN: 2621-4695, ISSN: 2620-7443.

[6] Adrianto; Syamsurizaldi; Zetra, Aidinil. Management of the Tourism Destination Development Program by the Kerinci Regency Tourism, Culture, Youth and Sports Agency. JAKP (Journal of Administration and Public Policy). 2018. Volume III, Nomor 3; ISSN: 2301-4342.

[7] Ristarnado; Settyoko, Joko; Harpinsyah. Village Government Strategy in Developing Tourism. Journal of Politics and Regional Government. 2019. Volume I, Nomor 1; pp. 40-51.

[8] Soka, Aleksius Beatus Ringgi; Sasingko, Tatok; Setyawan, Dodi. Village Government Strategies in Increasing Community Income through the Home Industry Sector. Journal of Social and Political Sciences. 2012. Volume I, Nomor 1; ISSN. 2442-6962.

[9] Mardianis; Syartika, Hanibal. Contribution of the Tourism Sector to Regional Original Income (PAD) in Kerinci Regency. Journal of Economics and Public Policy. 2018. Volume 9, Nomor 1; E-ISSN: 2528-4673 P-ISSN: 2086-6313.

[10] Chaseimera, Azita Yeja; Mahagangga, Agung Okta. The Strategy for Tourism Development of the Earth Sakti Alam Kerinci, Kerinci Regency, Jambi Province. Journal of Tourism Destinations. 2016. Volume 4, Nomor 2; ISSN: 2338-8811.

[11] Sidauruk, Rosmawaty. Enhancing The Role Of Local Government In Order In West Java Province. Jurnal Bina Praja. 2013. Volume 5, Nomor 3; hal 141-158.

[12] Hastuti, Tuti; Marjani AT; Endah, Puspitasari. Creative Economy Development Strategy in Malang Raya. Conference on Innovation and Application of Science and Technology (CIASTECH). 2019. ISSN Cetak : 2622-1276, ISSN Online : 2622-1284.

[13] Satria, Edia. Analysis of the Promotion Strategy of the Tourism and Culture Office in Increasing the Number of Tourist Visits in Kerinci Regency. Scientific Journal of Economics and Business. 2018. Volume 9, Nomor 1. 